\title{
Molecular characterization of twenty polymorphic microsatellite markers in the polyploid fruit tree species Syzygium samarangense (Myrtaceae)
}

\author{
J.M. Lai ${ }^{1,2 *}$, C.C. Tsai ${ }^{1,2 *}$, C.R. Yen ${ }^{2}$, Y.Z. Ko ${ }^{3}$, S.R. Chen ${ }^{1}$, I.S. Weng ${ }^{1}$, Y.S. Lin ${ }^{1}$ \\ and Y.C. Chiang ${ }^{3,4 *}$ \\ ${ }^{1}$ Kaohsiung District Agricultural Research and Extension Station, Pingtung, Taiwan \\ ${ }^{2}$ National Pingtung University of Science and Technology, Pingtung, Taiwan \\ ${ }^{3}$ Department of Biological Sciences, National Sun Yat-sen University, Kaohsiung, \\ Taiwan \\ ${ }^{4}$ Department of Biomedical Science and Environment Biology, \\ Kaohsiung Medical University, Kaohsiung, Taiwan \\ *These authors contributed equally to this study. \\ Corresponding author: Y.C. Chiang \\ E-mail: yuchung@mail.nsysu.edu.tw
}

Genet. Mol. Res. 14 (4): 13013-13021 (2015)

Received April 23, 2015

Accepted August 19, 2015

Published October 21, 2015

DOI http://dx.doi.org/10.4238/2015.October.21.22

\begin{abstract}
Syzygium samarangense (Blume) Merr. \& Perry (wax apple) is an important commercial fruit tree in Southeast Asia. Here, microsatellite markers were developed to evaluate genetic diversity and distinguish cultivars in this species. In total, 161 microsatellite loci with sufficient flanking sequences to design primer sets were isolated from wax apple using a magnetic bead-enrichment method. Fifty-eight primer sets were designed based on the flanking sequences of each single sequence repeat (SSR) locus and were tested using 14 wax apple cultivars/lines. Twenty SSR loci were found to be polymorphic and transferable across the 14 wax apple cultivars/lines. The number of alleles and effective number of alleles detected per locus ranged from 4 to 12 and from 1.697 to 9.800 , respectively.
\end{abstract}


The expected heterozygosity ranged from 0.150 to 0.595 (mean $=0.414$ ) . Polymorphism information content values ranged from 0.502 to 0.866 (mean $=0.763$ ). These new microsatellite loci will be of value for characterization of genetic diversity in wax apples and for the identification of cultivars.

Key words: Syzygium samarangense; Genetic diversity; Microsatellite; DNA marker

\section{INTRODUCTION}

Syzygium samarangense (Blume) Merr. \& Perry, family Myrtaceae, is a popular tropical fruit tree that has several common names, including wax apple, rose apple, and java apple. The genus Syzygium contains approximately 1200 species (Tuiwawa et al., 2013) and several are cultivated for their fruit. Syzygium species are polyploid with chromosome numbers ranging from $2 n=22$ in S. maire to $2 n=110$ in S. samarangense (Roy and Jha, 1962). Wax apples are native to Borneo, Sumatra, Java, Sulawesi, Malay Peninsula, and the Andaman and Nicobar Islands (Morton, 1987). The size, shape, and color of the fruit vary among commercial cultivars; the fruit is usually pink, light-red, red, green, or cream-colored (Morton, 1987). At present, wax apples are widely cultivated in tropical areas and are a commercially important crop in Taiwan (Yaacob and Subhadrabandhu, 1995). Breeding programs have been established in Japan to improve the color, taste, flavor, and size of the fruits and several cultivars with large fruits have been selected for commercial use. Nevertheless, at the present time, wax apples have relatively fewer cultivars than other economically important fruit trees (Morton, 1987).

Recently, several types of DNA marker have been applied to characterize cultivars, for example, amplified fragment length polymorphisms (AFLPs) (Kashkush et al., 2001), inter-simple sequence repeat (ISSRs) (Eiadthong et al., 1999), and microsatellite markers (simple sequence repeats, SSRs) (Tsai et al., 2013). Of these, SSR markers have several advantages, such as their high reliability, high polymorphism, codominance, and transferability among related species (Rafalski et al., 1996). Therefore, SSR markers have proven to be informative for studying genetic relationships among closely related plant species, as well as among subpopulations of a single species (Bowcock et al., 1994). Microsatellites are tandem repeats of short (2-6 bp) DNA sequences. Microsatellite markers from tropical fruits have been isolated and characterized, including mango (Chiang et al., 2012), Indian Jujube (Chiou et al., 2012), and guava (Rai et al., 2013).

ISSRs (Qiao et al., 2006) and random amplified polymorphic DNA markers (RAPDs) have been used previously to investigate the genetic relationships among wax apple cultivars/lines (Chiu et al., 2009). However, no SSR loci for wax apples have been developed to date. In this study, we isolated and characterized several SSR markers in the wax apple. These SSR markers can be applied to examination of the genetic diversity in this species and to identification of different cultivars/lines.

\section{MATERIAL AND METHODS}

\section{Plant material and DNA isolation}

Fourteen wax apple cultivars/lines cultivated at Kaohsiung District Agricultural Research and Extension Station (KDARES), Taiwan were sampled for this study. Total genomic DNA was extracted from young leaves using a Plant Genomic DNA Extraction Kit (RBC Bioscience, Taipei, Taiwan) following the manufacturers protocol (Table 1). 
Table 1. Wax apple cultivars/lines used in this study.

\begin{tabular}{llll}
\hline Taxa no. & Cultivars/lines & Origin & Genetic background \\
\hline 1 & Pink & Taiwan & unknown \\
2 & Big Fruit - line 1 & Taiwan & unknown \\
3 & Big Fruit - line 2 & Taiwan & unknown \\
4 & Thub Thim Chan & Thailand & unknown \\
5 & Bullet & Thailand & unknown \\
6 & Indonesia Big Fruit & Indonesia & unknown \\
7 & Indo Red & Thailand & unknown \\
8 & Green Diamond-1 & Thailand & unknown \\
9 & Green Diamond-2 & Thailand & unknown \\
10 & Vietnam Pink & Vietnam & unknown \\
11 & Line kws087 & Taiwan & unknown \\
12 & Line kws107 & Taiwan & unknown \\
13 & Line kws112-1 & Taiwan & unknown \\
14 & Line kws112-2 & Taiwan & unknown \\
\hline
\end{tabular}

\section{Cloning and sequencing of SSR loci}

Microsatellite loci were isolated using the modified AFLP and magnetic bead enrichment method (Ho et al., 2014; Tsai et al., 2014). Genomic DNA from S. samarangense 'Pink' was digested using Msel (Promega, Madison, Wisconsin, USA) and separated by $1.2 \%$ agarose gel electrophoresis using a Tris-boric acid-EDTA buffer system. DNA fragments from 400 to $1000 \mathrm{bp}$ were isolated from the agarose gel using a HiYield Gel PCR DNA Fragments Extraction Kit (RBC Bioscience) and ligated to a double-stranded adaptor (complementary oligo A, 5'-TACTCAGGACTCAT-3', and a 5'-phosphorylated oligo B, 5'-GACGATGAGTCCTGAG-3'). The partial Msel-digested library was enriched using PCR with $20 \mathrm{ng}$ template DNA, 10 pmol adapterspecific primers (5'-GATGAGTCCTGAGTAAN-3'), $2 \mu \mathrm{l}$ 10X reaction buffer, $2 \mathrm{mM}$ dNTP mix, 2 $\mathrm{mM} \mathrm{MgCl}, 0.5 \cup$ Taq DNA polymerase (Promega), and sterile water to bring the volume to $20 \mu \mathrm{l}$. Amplification was performed using a Labnet MultiGene 96-well Gradient Thermal Cycler (Labnet, Edison, New Jersey, USA) with the following conditions: $94^{\circ} \mathrm{C}$ for $5 \mathrm{~min}$ for the initial denaturation, followed by 15 cycles at $94^{\circ} \mathrm{C}$ for $30 \mathrm{~s}, 53^{\circ} \mathrm{C}$ for $1 \mathrm{~min}$, and $72^{\circ} \mathrm{C}$ for $1 \mathrm{~min}$ The amplicons were purified, denatured, and incubated with two different biotinylated probes $\left[(A G)_{15}\right.$ and $\left.(A C)_{15}\right]$ at $68^{\circ} \mathrm{C}$ for $1 \mathrm{~h}$ for the hybridization of the potential microsatellite sequence fragments. The DNA fragments were hybridized to the probes and then captured by Streptavidin MagneSphere Paramagnetic Particles (Promega). The enriched DNA fragments were purified and used as templates for 25 cycles of PCR amplification using $5 \mu \mathrm{l}$ purified captured DNA fragments, 10 pmol adapter-specific primers (5'-GATGAGTCCTGAGTAAN-3'), $2 \mu$ l0X reaction buffer, $2 \mathrm{mM}$ dNTP mix, $2 \mathrm{mM} \mathrm{MgCl}_{2}$, $0.5 \cup$ Taq DNA polymerase (Promega), and sterile water to bring the mixture up to $20 \mu l$. The amplification conditions were 25 cycles of denaturation at $94^{\circ} \mathrm{C}$ for $3 \mathrm{~min}, 1 \mathrm{~min}$ annealing at $53^{\circ} \mathrm{C}$, and 1 min extension at $72^{\circ} \mathrm{C}$. The purified PCR products were cloned directly into the $p$ GEM-T Easy Vector System (Promega) and transformed into E. coli DH5a cells. Positive colonies were selected, and their plasmids were extracted using the QIAprep Spin Miniprep Kit (Qiagen, Hilden, Germany). The selected plasmids were subsequently sequenced in both directions by the fluorescence dideoxy method using an ABI BigDye3.1 Terminator Cycle Sequencing Kit (Applied Biosystems, California, USA). A total reaction volume of $20 \mu \mathrm{l}$, containing $200 \mathrm{ng}$ purified plasmid DNA, $0.5 \mathrm{mM}$ T7 or SP6 primers, and $4 \mu \mathrm{l}$ Big Dye Terminator v3.1 Ready Reaction Premix Reactions (Applied Biosystems), was used with the ABI PRISM 3700 DNA Sequencer (Applied Biosystems). 


\section{SSR mining and primer design and PCR amplification and electrophoresis}

SSR enriched sequencing data were mined using Tandem Repeats Finder version 4 (Benson, 1999). Primer pairs for the SSR loci were designed using the flanking sequences with FastPCR software version 5.4 (Kalendar, 2009). The optimal annealing temperature was determined by gradient PCR with a T-gradient PCR Machine (Biometra, Goettingen, Germany).

For the purposes of this study, the designed forward primers for 20 SSR markers were elongated from the M13 (-21) 18 bp sequence (5'-TGTAAAACGACGGCCAGT-3') by fluorescent labeling (Schuelke, 2000). The designed primer pairs were first tested for PCR amplification and then used to test the 14 wax apple cultivars/lines. For PCR, a total volume of $25 \mu$ with $20 \mathrm{ng}$ of temple DNA, 1X PCR buffer, $0.2 \mathrm{mM}$ of each dNTP, $0.2 \mathrm{mM}$ of each SSR specific primer and $0.25 \mathrm{U}$ Taq DNA polymerase (Promega) was used. Two-step PCR amplification was performed. The first step involved initial denaturation at $94^{\circ} \mathrm{C}$ for $3 \mathrm{~min}$, followed by 20 cycles of $30 \mathrm{~s}$ denaturation at $94^{\circ} \mathrm{C}, 30 \mathrm{~s}$ annealing at $58^{\circ} \mathrm{C}, 40 \mathrm{~s}$ extension at $72^{\circ} \mathrm{C}$, and a final extension for $7 \mathrm{~min}$ at $72^{\circ} \mathrm{C}$. Subsequently, $0.075 \mathrm{mM} \mathrm{M} 13$ primer $5^{\prime}$-labeled with IRDye was added to the PCR mixture. The second amplification step involved initial denaturation at $94^{\circ} \mathrm{C}$ for $3 \mathrm{~min}$, followed by 10 cycles of $30 \mathrm{~s}$ denaturation at $94^{\circ} \mathrm{C}, 30 \mathrm{~s}$ annealing at $58^{\circ} \mathrm{C}, 40 \mathrm{~s}$ extension at $72^{\circ} \mathrm{C}$, and a final extension for $7 \mathrm{~min}$ at $72^{\circ} \mathrm{C}$. Samples were denaturated in loading dye $(10 \mathrm{mg} / \mathrm{ml}$ blue dextran in formamide) and separated by $6.5 \%$ polyacrylamide gel electrophoresis (19:1, 7M urea) in an LI-COR 4300 DNA analyzer (LI-COR, Lincoln, Nebraska USA). Fragment lengths were determined using an external standard (50-500 bp, GE Healthcare, USA) and with in-house amplified internal standards using Allele Locator 1.03 software (Amersham Biosciences).

\section{Statistical analysis}

The degree of polymorphism, including the number of alleles $\left(N_{A}\right)$ and the number of effective alleles $\left(N_{E}\right)$ were computed using SPAGeDi (Hardy and Vekemans 2002). Hardy-Weinberg expected heterozygosity $\left(H_{E}\right)$, Shannon-Wiener diversity Index $\left(H^{\prime}\right)$, and Evenness $(E)$ were computed by ATETRA v.1.2 (van Puyvelde et al., 2010). The polymorphism information content (PIC) was computed using PowerMarker version 3.25 (Liu and Muse, 2005). Evaluated genetic components and genotypic group structures for 14 wax apple lines were determined using Bayesian-clustering analysis with STRUCTURE ver. 2.3.3 (Evanno et al., 2005). The admixture model was used and a posterior probability of $\mathrm{K}$ from 1 to 14 was calculated by the Markov chain Monte Carlo (MCMC) method using 20 separate runs to evaluate the consistency of the results. Each run was calculated as $10,000,000$ steps with a 1,000,000-step burn-in. The best fit grouping number was evaluated using $\triangle \mathrm{K}$ (Evanno et al., 2005) by STRUCTURE HARVESTER v. 0.6.8 (Earl and vonHoldt, 2012). A final $10,000,000$ replications with a 1,000,000-step burn-in were performed using the best $\mathrm{K}$.

\section{RESULTS AND DISCUSSION}

In total, our isolation and characterization of SSR markers in wax apple yielded 441 microsatellite loci from 666 selected cloned sequences. Flanking sequences of the microsatellites were used to design primer pairs. However, some cloned sequences did not have sufficient flanking regions to enable design of specific primers on one or both sides of the SSR locus. After screening of the cloned SSR loci, PCR amplification for all of the SSR loci was possible. Of the 441 SSR loci, 161 had sufficient flanking sequences to design primer sets, 103 SSR loci were abnegated based on the detection of ambiguous amplicons, and 58 SSR loci were screened for polymorphism in the 
study. The optimal annealing temperature for PCR tends to vary among different SSRs (Ai et al., 2008; Hsu et al., 2013; Hung et al., 2014). To enhance the process, a similar melting temperature $(\mathrm{Tm})$ value was set for the designation of all SSR locus primers. The PCR products were separated on $1 \%$ agarose gels to evaluate the optimal annealing temperature. After screening the PCR conditions by a T-gradient PCR Machine, the universal annealing temperature of PCR amplification for all of SSR loci was set at $58^{\circ} \mathrm{C}$ (Table 2).

Table 2. Characteristics of 20 microsatellite loci isolated from wax apples (Ta, annealing temperature).

\begin{tabular}{|c|c|c|c|c|}
\hline SSR locus & Primers $\left(5^{\prime} \rightarrow 3^{\prime}\right)$ & Allele size & Repeat motif (bp) & $\mathrm{Ta}\left({ }^{\circ} \mathrm{C}\right)$ \\
\hline Ssa-5 & $\begin{array}{l}\text { F: CGGAGGTACAGACGACTCACCA } \\
\text { R: GAAAGAAACCCCGTTTTGACC }\end{array}$ & $230-254$ & $(G A)_{16}$ & 58 \\
\hline Ssa-14 & $\begin{array}{l}\text { F: AACACGACAGGGCGCCTCT } \\
\text { R: CAGTTATCAACTCTCGTTATCAC }\end{array}$ & 178-194 & $(\mathrm{GA})_{18}$ & 58 \\
\hline Ssa-110 & $\begin{array}{l}\text { F: TTCTTCTTCGCCATCGCTG } \\
\text { R: AGAATCAAAGACGATGATGGCC }\end{array}$ & 269-295 & $(\mathrm{ACGC})_{7}(\mathrm{AGCG})_{6}(\mathrm{GA})_{4}$ & 58 \\
\hline Ssa-116 & $\begin{array}{l}\text { F: GGATAAAAATGCGGATGTGGG } \\
\text { R: TCCTTTGGGCTCACAAGGGT }\end{array}$ & 143-193 & $(A G)_{21}$ & 58 \\
\hline Ssa-134 & $\begin{array}{l}\text { F: CATAGCCTTTTCAACAAGGGC } \\
\text { R: CGTGTATTCAGACAACTGCC }\end{array}$ & $126-164$ & $(\mathrm{AG})_{31}$ & 58 \\
\hline Ssa-268 & $\begin{array}{l}\text { F: GCAGACAGACTCTATGCACG } \\
\text { R: TGAGGTCAATCCTAAGCCA }\end{array}$ & 120-172 & $(A G)_{34}$ & 58 \\
\hline Ssa-269 & $\begin{array}{l}\text { F: CAGATCCCTTTCCTCTTATC } \\
\text { R: ACACAACACCGTCCTTCGT }\end{array}$ & 209-263 & $(\mathrm{GA})_{31}$ & 58 \\
\hline Ssa-300 & $\begin{array}{l}\text { F: AGTCCAAGCCAACAGCACA } \\
\text { R: TGGGATCACCGGCCCAAGT }\end{array}$ & 243-281 & $(\mathrm{TC})_{24}$ & 58 \\
\hline Ssa-307 & $\begin{array}{l}\text { F: GTGCAATTGGCAAGCAAGA } \\
\text { R: AAGTTTTGGCCGGAAAAAGC }\end{array}$ & 190-206 & $(\mathrm{AG})_{25}$ & 58 \\
\hline Ssa-315 & $\begin{array}{l}\text { F: CTGTATTCTGACTGGGTTGC } \\
\text { R: TTTTGCTTGCCCTGGTAGC }\end{array}$ & $144-210$ & $(A G)_{41}$ & 58 \\
\hline Ssa-341 & $\begin{array}{l}\text { F: ATGGGTTAGCGACCGATCA } \\
\text { R: ATGAGTGGGACTTTCCGCT }\end{array}$ & 224-254 & $(A G)_{24}$ & 58 \\
\hline Ssa-391 & $\begin{array}{l}\text { F: ACCTGGACGATGGTTGTGG } \\
\text { R: AGAGCCTTTGGATCTTGGCT }\end{array}$ & 267-369 & $(A G)_{51}$ & 58 \\
\hline Ssa-402 & $\begin{array}{l}\text { F: CTCAGCTGTCCATGCCCCT } \\
\text { R: ACCAACACTCACTCCCACA }\end{array}$ & 226-284 & $(A G) 21 N(G A)_{22}$ & 58 \\
\hline Ssa-407 & $\begin{array}{l}\text { F: GGGCTGCTAAAATCGCCCA } \\
\text { R: CCCGATCTGAGGTTGTCGA }\end{array}$ & 149-199 & $(\mathrm{TC})_{33}$ & 58 \\
\hline Ssa-423 & $\begin{array}{l}\text { F: AGTTGGCACTTTTTGGCCCAGC } \\
\text { R: CCGGTCAAACCCATGCCGT }\end{array}$ & 196-254 & $(G A)_{38}$ & 58 \\
\hline Ssa-444 & $\begin{array}{l}\text { F: ACGACGGAAAGGCGGGGTTAC } \\
\text { R: TCGTTCACACGTTCCTCGGA }\end{array}$ & $269-313$ & $(A G)_{23}$ & 58 \\
\hline Ssa-462 & $\begin{array}{l}\text { F: ACAGATCGCTGAAGCGAGG } \\
\text { R: ACAGGTTTCTCGTGAATCC }\end{array}$ & $269-330$ & $(\mathrm{GA})_{29}$ & 58 \\
\hline Ssa-498 & $\begin{array}{l}\text { F: ATGGGAAAAATCTCTGACCGT } \\
\text { R: ACTGTACTGTTTAGTAGGCC }\end{array}$ & $87-121$ & $(\mathrm{CT})_{28}$ & 58 \\
\hline Ssa-583 & $\begin{array}{l}\text { F: CCCTAAATGGCCTCAACGT } \\
\text { R: CCTGAGTAAAGATATGGTGC }\end{array}$ & 227-303 & $(G A)_{27}$ & 58 \\
\hline Ssa-616 & $\begin{array}{l}\text { F: GCAAAATCGGTGATGCTGC } \\
\text { R: AAATTAGGGGGGACTCTCA }\end{array}$ & 253-321 & $(\mathrm{AG})_{37}$ & 58 \\
\hline
\end{tabular}

Twenty of the 58 SSR markers used to screen for polymorphism showed transferability across the 14 wax apple cultivars/lines (Table 3). Since wax apple is a polyploid species (Roy and Jha, 1962), more than two PCR products may be present for an individual tree, as shown in Figure 1. Compared to other DNA markers, genetic polymorphism derived from SSR markers is generally high because of allelic diversity due to replication slippage (Levinson and Gutman, 1987). Other DNA markers identify nucleotide mutations, insertions, or deletions (Spandana et al., 2012). All isolated SSR primer pairs that were amplified were clearly distinguishable and polymorphic. These microsatellite loci yielded a total of 140 polymorphic alleles from the 14 wax apple cultivars/lines. 
Table 3. Genetic diversity in 14 wax apple cultivars/lines.

\begin{tabular}{|c|c|c|c|c|c|c|}
\hline SSR locus & $N_{\mathrm{A}}$ & $N_{\mathrm{E}}$ & $H_{\mathrm{E}}$ & $\mathrm{H}^{\prime}$ & $E$ & PIC \\
\hline Ssa-5 & 7 & 3.532 & 0.417 & 0.662 & 1.976 & 0.803 \\
\hline Ssa-14 & 5 & 1.697 & 0.478 & 0.769 & 2.166 & 0.648 \\
\hline Ssa-110 & 4 & 7.358 & 0.356 & 0.050 & 0.474 & 0.502 \\
\hline Ssa-116 & 7 & 3.119 & 0.404 & 0.614 & 1.834 & 0.818 \\
\hline Ssa-134 & 6 & 3.745 & 0.433 & 0.657 & 1.884 & 0.866 \\
\hline Ssa-268 & 6 & 5.215 & 0.387 & 0.581 & 1.761 & 0.685 \\
\hline Ssa-269 & 4 & 3.325 & 0.150 & 0.218 & 1.267 & 0.520 \\
\hline Ssa-300 & 5 & 3.462 & 0.252 & 0.376 & 1.483 & 0.831 \\
\hline Ssa-307 & 6 & 4.642 & 0.447 & 0.688 & 1.951 & 0.792 \\
\hline Ssa-315 & 10 & 6.157 & 0.479 & 0.804 & 2.365 & 0.786 \\
\hline Ssa-341 & 7 & 3.720 & 0.475 & 0.766 & 2.158 & 0.831 \\
\hline Ssa-391 & 10 & 3.500 & 0.595 & 1.008 & 2.809 & 0.806 \\
\hline Ssa-402 & 5 & 4.729 & 0.299 & 0.042 & 0.399 & 0.779 \\
\hline Ssa-407 & 7 & 8.129 & 0.328 & 0.495 & 1.658 & 0.831 \\
\hline Ssa-423 & 11 & 9.800 & 0.372 & 0.569 & 1.777 & 0.866 \\
\hline Ssa-444 & 9 & 4.546 & 0.491 & 0.013 & 0.655 & 0.844 \\
\hline Ssa-462 & 6 & 3.532 & 0.358 & 0.050 & 0.477 & 0.602 \\
\hline Ssa-498 & 7 & 1.697 & 0.455 & 0.025 & 0.606 & 0.786 \\
\hline Ssa-583 & 12 & 7.358 & 0.530 & 0.004 & 0.706 & 0.866 \\
\hline Ssa-616 & 6 & 3.119 & 0.574 & 0.940 & 2.495 & 0.806 \\
\hline Mean & 7 & 4.448 & 0.414 & 0.467 & 1.545 & 0.763 \\
\hline
\end{tabular}

$N_{\mathrm{A}}=$ number of alleles, $H_{\mathrm{E}}=$ mean of Hardy-Weinberg expected heterozygosity, $\mathrm{H}^{\prime}$ = mean of Shannon-Wiener diversity Index, $\mathrm{E}=$ mean of evenness, $\mathrm{PIC}=$ polymorphism information content.

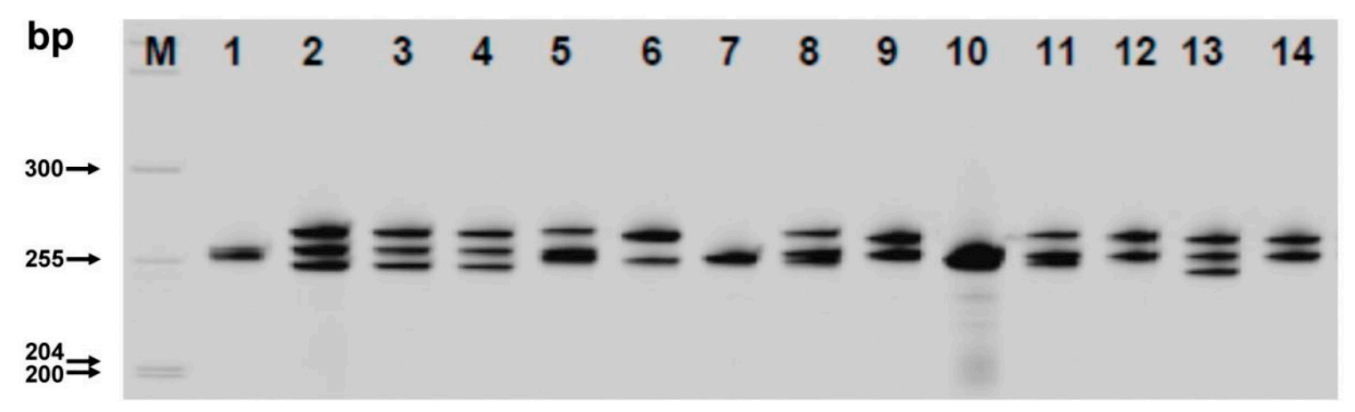

Figure 1. Analysis of polymorphism in 14 wax apple cultivars/lines using the Sys-5 SSR locus. M: DNA marker. Lanes 1-14 represent the different cultivars/lines (see Table 1).

The PIC values obtained by the 20 polymorphic SSRs ranged from 0.502 (Ssa-110 SSR locus) to 0.866 (Ssa-134, Ssa-423 and Ssa-583 SSR loci), with a mean of 0.763 (Table 3). The PIC value is an indicator of how useful DNA markers are for investigating genetic relationships, genetic mapping, and cultivar identification (Spandana et al., 2012). Markers with higher PIC values have greater potential at revealing allelic variation. SSR loci with low repeat numbers have monomorphic or low PIC values (Saghai Maroof et al., 1994). However, some studies have not found a positive correction between repeat numbers and PIC values (Budak et al., 2003). In the current study, the degree of polymorphism detected by these primer pairs was not correlated with the number of microsatellite repeats (Table 3).

Other aspects of polymorphism were also evaluated, including allele number, the number of alleles $\left(N_{A}\right)$, the effective number of alleles $\left(N_{E}\right)$, and the expected heterozygosity $\left(H_{E}\right)$. A total of 140 alleles was found, ranging from 4 to 12 per locus (Table 3 ), with a mean of 7 . The locus with 
the highest allele number was Ssa-583 (12 alleles). $N_{E}$ ranged from 1.697 to 9.800 , with a mean of 4.448 per locus. $H_{E}$ ranged from 0.150 (Ssa-269) to 0.595 (Ssa-391), with a mean of 0.414 . The $H_{E}$ value was similar to that obtained for other tropical fruit trees, including mango cultivars (Chiang et al., 2012) and Indian jujube cultivars (Chiou et al., 2012). However, the $\mathrm{Ne}$ and $H_{E}$ values of wax apple were noticeably lower than those of Japanese plum cultivars (Carrasco et al., 2012) and apple cultivars (Sikorskaite et al., 2012). Both Japanese plum and apple cultivars have strong self-incompatibility (Okie and Weinberger, 1996; Hegedus, 2006) compared to the wax apple, which is a self-compatible species (Chantaranothai and Parnell, 1994). Self-incompatibility tends to maintain a high degree of heterogeneity in crops (Wang et al., 2006).

To evaluate the consistency of genetic components in certain cultivated lines of wax apple introduced into Taiwan, we performed an assignment test of genetic composition with the assistance of STRUCTURE v. 2.3.3. A Bayesian clustering analysis inferred that two clusters was the best fit in the $\Delta \mathrm{K}$ evaluation $(\Delta \mathrm{K}=82.506)$ of the 20 microsatellite loci. Based on this analysis, the 14 wax apple lines can be divided into two major groups (Figure 2) that are distinct genetic units with either a high percentage of composition 1 (orange color in Figure 2) or composition 2 (blue color in Figure 2 ); this indicates that at least two different sources of wax apple were introduced into Taiwan. The results also show that the assignment test using our newly developed microsatellite markers is a powerful tool to identify distinct genetic units without prior knowledge of past introductions (Liao et al., 2012) or evolutionary history (Ge et al., 2012; 2015).

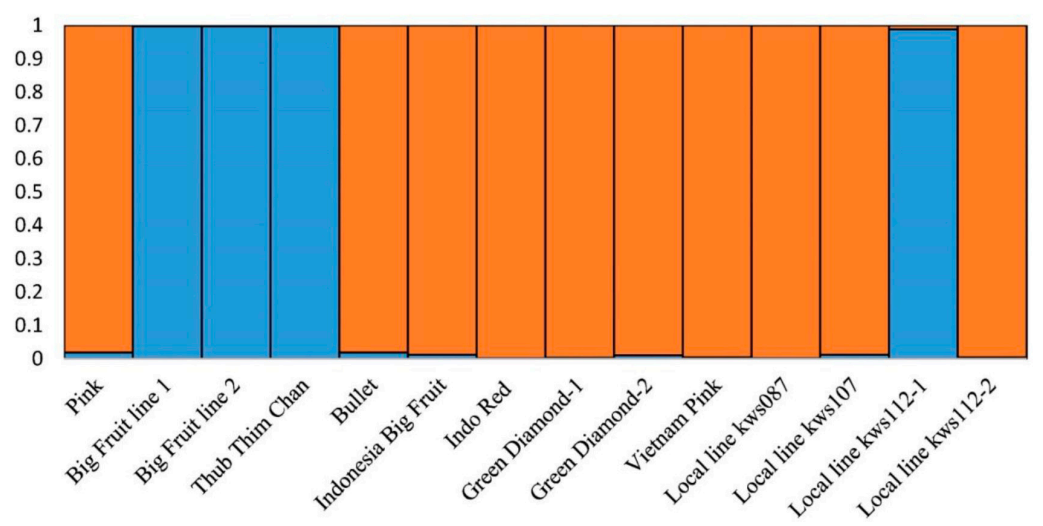

Figure 2. Genotypic group structure of 14 wax apple lines (Table 1) estimated by Bayesian-clustering analysis with the STRUCTURE program (Pritchard et al., 2000) and using the 20 polymorphic microsatellite loci. Each individual plot is indicated by the name of the wax apple sample. The best fit was two groups ; the 14 wax apple lines are shown in their inferred major groups by orange and blue coloration, respectively.

\section{CONCLUSION}

In conclusion, the 20 new primer sets for wax apple microsatellite loci reported here will be of value for evaluating genetic diversity, developing a standard operating procedure for cultivar identification, analyzing lineage, and the development of linkage maps in this species.

\section{Conflicts of interest}

The authors declare no conflict of interest. 


\title{
ACKNOWLEDGMENTS
}

\author{
Research funded by the Ministry of Science and Technology (former National Science \\ Council), Executive Yuan, Taiwan.
}

\section{REFERENCES}

Ai CX, Yu XM, Dahlenburg A, Zhao HJ, et al. (2008). Development and characterization of SSR markers in Chinese cherry (Prunus pseudocerasus Lindl.). Eur. J. Hort. Sci. 73: 104-110.

Benson G (1999). Tandem repeats finder: a program to analyze DNA sequences. Nucleic Acids Res. 27: 573-580.

Bowcock AM, Ruiz-Linares A, Tomfohrde J, Minch E, et al. (1994). High resolution human evolutionary trees with polymorphic microsatellites. Nature 368: 455-457.

Budak H, Pedraza F, Cregan PB, Baenziger PS, et al. (2003). Development and utilization of SSRs to estimate the degree of genetic relationships in a collection of pearl millet germplasm. Crop Sci. 43: 2284-2290.

Carrasco B, Díaz C, Moya M, Gebauer M, et al. (2012). Genetic characterization of Japanese plum cultivars (Prunus salicina) using SSR and ISSR molecular markers. Cien. Inv. Agr. 39: 533-543.

Chantaranothai P and Parnell JAN (1994). The Breeding Biology of Some Thai Syzygium Species. Trop. Ecol. 35: 199-208.

Chiang YC, Tsai CM, Chen YK, Lee SR, et al. (2012). Development and characterization of 20 novel microsatellite markers from mango (Mangifera indica L.). Am. J. Bot. 99: e117-119.

Chiou CY, Chiang YC, Chen $\mathrm{CH}$, Yen CR, et al. (2012). Development and characterization of 38 microsatellite markers from an economically important fruit tree, the Indian jujube.). Am. J. Bot. 99: e199-202.

Chiu CC, Huang CC and Shü ZH (2009). Genetic relationships of the big-fruited wax apple-lines collected from Taiwan by random amplified polymorphic DNA (RAPD). J. Meiho Inst.Technol. 28: 167-176.

Earl DA and von Holdt BM (2012). STRUCTURE HARVESTER: a website and program for visualizing STRUCTURE output and implementing the Evanno method. Conserv. Genet. Resour. 4: 359-361.

Eiadthong W, Yonemori K, Sugiura A, Utsunomiya N, et al. (1999). Identification of mango cultivars of Thailand and evaluation of their genetic variation using the amplified fragments by simple sequence repeat- (SSR-) anchored primers. Sci. Hortic. 82: 57-66.

Evanno G, Regnaut S and Goudet J (2005). Detecting the number of clusters of individuals using the software STRUCTURE: a simulation study. Mol. Ecol. 14: 2611-2620.

Ge XJ, Hsu TW, Hung KH, Lin CJ, et al. (2012) Inferring mutiple refugia and phylogeographical patterns in Pinus massoniana based on nucleotide sequence variation and DNA fingerprinting. Plos One 7: e43717.

Ge XJ, Hung KH, Ko YZ, Hsu TW, et al. (2015). Genetic divergence and biogeographical patterns in Amentotaxus argotaenia species complex. Plant Mol. Biol. Rep. 33: 264-280.

Hardy $O$ and Vekemans $X$ (2002). SPAGeDi: a versatile computer program to analyse spatial genetic structure at the individual or population levels. Mol. Ecol. Notes. 2: 618-620.

Hegedus A (2006). Review of the self-incompatibility in apple (Malus x domestica Borkh., syn.: Malus pumila Mill.). Int. J. Hortic. Sci. 12: 31-36.

Ho CS, Shih HC, Liu HY, Chiu ST, et al. (2014). Development and characterization of 16 polymorphic microsatellite markers from Taiwan cow-tail fir, Keteleeria davidiana var. formosana (Pinaceae) and cross-species amplification in other Keteleeria taxa. BMC Res. Notes 7: 255.

Hsu TW, Shih HC, Kuo CC, Chiang TY, et al. (2013). Characterization of 42 microsatellite markers from poison ivy, Toxicodendron radicans (Anacardiaceae). Int. J. Mol. Sci. 14: 20414-20426.

Hung KH, Lin CH, Shih HC, Chiang CY, et al. (2014). Development, characterization and cross-species amplification of new microsatellite primers from an endemic species Cinnamomum kanehirae (Lauraceae) in Taiwan. Conserv. Genet. Resour. 6: 911-913.

Kalendar R (2009). FastPCR software for PCR primer and probe design and repeat search. (www.biocenter.helsinki.fi/bi/ programs/fastpcr.html).

Kashkush K, Jinggui F, Tomer E, Hillel J, et al. (2001). Cultivar identification and genetic map of mango (Mangifera indica). Euphytica 122: 129-136.

Levinson G and Gutman GA (1987). Slipped-strand mispairing: a major mechanism for DNA sequence evolution. Mol. Biol. Evol. 4: 203-221.

Liao PC, Tsai CC, Chou CH and Chiang YC (2012). Introgression between cultivars and wild populations of Momordica charantia L. (Cucurbitaceae) in Taiwan. Int. J. Mol. Sci. 13: 6469-6491.

Liu K and Muse SV (2005). PowerMarker: an integrated analysis environment for genetic marker analysis. Bioinformatics 21: 2128-2129. 
Morton J F (1987). Fruits of warm climates. Florida Flair Books, Miami, Florida, 381-382.

Okie WR and Weinberger JH (1996). Plums. In: Fruit breeding. Vol. I: Tree and tropical fruit. (Janick J and Moore JN eds.). John Wiley and Sons, Inc., New York.

Qiao H, Lu LG, Hui XJ and Cai LW (2006). Genetic diversity analysis of wax apple germplasm by ISSR markers. Acta Hortic. Sin. 33: 392-394.

Rafalski JA, Vogel JM, Morgante M, Powell W, et al. (1996). Generating and using DNA markers in plants. In: Nonmammalian genomic analysis. A practical guide (Birren B and Lai E, eds.). Academic Press, San Diego, 75-134.

Rai MK, Phulwaria M and Shekhawat NS (2013). Transferability of simple sequence repeat (SSR) markers developed in guava (Psidium guajava L.) to four Myrtaceae species. Mol. Biol. Rep. 40: 5067-5071.

Roy RP and Jha RP (1962). Cytological studies in Myrtaceae. Proceedings 49th Indian Science Congress 3: 336.

Saghai Maroof MA, Biyashev RM, Yang GP, Zhang Q, et al. (1994). Extraordinarily polymorphic microsatellite DNA in barley: species diversity, chromosomal locations, and population dynamics. Proc. Natl. Acad. Sci. U.S.A. 91: 5466-5470.

Schuelke M (2000). An economic method for the fluorescent labeling of PCR fragments. A poor man's approach to genotyping for research and high-throughput diagnostics. Nature Biotechnol. 18: 233-234.

Sikorskaite S, Gelvonauskiene D, Stanys V and Baniulis D (2012). Characterization of microsatellite loci in apple (Malus $\mathrm{x}$ domestica Borkh.) cultivars. Zemdirbyste 99: 131-138.

Spandana B, Reddy VP, Prasanna GJ, Anuradha G, et al. (2012). Development and characterization of microsatellite markers (SSR) in Sesamum (Sesamum indicum L.) species. Appl. Biochem. Biotechnol. 15: 1594-1607.

Tsai CC, Chen YK, Chen CH, Weng IS, et al. (2013). Cultivar identification and genetic relationship among Taiwanese mango cultivars using 37 SSR markers. Sci. Hortic. 164: 196-201.

Tsai CC, Wu PY, Kuo CC, Huang MC, et al. (2014). Analysis of Microsatellites in The Vulnerable Orchid Gastrodia Flavilabella: the Development of Microsatellite Markers and Cross-species Amplification in Gastrodia. Bot. Stud. 55: 72.

Tuiwawa SH, Craven LA, Sam C and Crisp MD (2013). The genus Syzygium (Myrtaceae) in Vanuatu. Blumea 58: 53-67.

Van Puyvelde K, van Geert A and Triest L (2010). ATETRA, a new software program to analyze tetraploid microsatellite data: comparison with TETRA and TETRASAT. Mol. Ecol. Resour. 10: 331-334.

Wang ML, Chen ZB, Barkley NA, Newman ML, et al. (2006). Characterization of seashore Paspalum (Paspalum vaginatum Swartz) germplasm by transferred SSRs from wheat, maize and sorghum. Genet. Resour. Crop Evol. 53: 779-791.

Yaacob O and Subhadrabandhu S (1995). The production of economic fruits in South-East Asia. Oxford University Press, Kuala Lumpur. 